\title{
PEMETAAN PARTISIPATIF UNTUK ESTIMASI KERUGIAN AKIBAT BANJIR ROB DI KABUPATEN PEKALONGAN
}

\author{
Muh Aris Marfai ${ }^{1}$, Ahmad Cahyadi ${ }^{2}$, Achmad Arief Kasbullah ${ }^{3}$, Luthfi Annur Hudaya ${ }^{4}$ \\ dan Dela Risnain Tarigan ${ }^{5}$ \\ 1,2,3 Jurusan geografi Lingkungan Fakultas Geografi Universitas Gadjah Mada \\ ${ }^{4,5}$ Program Studi IImu Lingkungan Sekolah Pascasarjana UGM \\ Email: arismarfai@yahoo.com, ahmadcahyadi@geo.ugm.ac.id
}

\begin{abstract}
ABSTRAK
Banjir rob merupakan salah satu bencana yang terjadi di Wilayah Kepesisiran Kabupaten Pekalongan. Kenaikan muka air laut yang sekaligus diiringi dengan penurunan muka tanah (subsidence) menyebabkan bencana rob di masa mendatang dikhawatirkan akan memiliki dampak yang semakin besar bagi kehidupan manusia. Penelitian ini bertujuan untuk (1) melakukan pemodelan genangan banjir rob berdasarkan pemetaan partisipatif di Wilayah Kepesisiran Kebupaten Pekalongan, dan (2) mengestimasi kerugian yang ditimbulkan oleh bencana banjir rob di Wilayah Kepesisiran Kabupaten Pekalongan.

Data yang digunakan dalam penelitian ini meliputi peta penggunaan lahan, data titiktitik ketinggian yang digunakan untuk membangun digital elevation model wilayah kajian, serta data skenario genangan berdasarkan pada pemetaan partisipatif dengan wawancara mendalam. Pemodelan genangan banjir rob dilakukan dengan menggunakan operasi ketetanggaan dengan menggunakan software I/wis. Perhitungan kerugian dilakukan berdasarkan perkalian antara luas penggunaan lahan yang tergenang dengan nilai ekonomi dari masing-masing penggunaan lahan.

Hasil analisis menunjukkan bahwa ketinggian banjir rob yang sering terjadi adalah sebesar $117 \mathrm{~cm}$, sedangkan banjir rob yang paling tinggi yang pernah terjadi adalah $133 \mathrm{~cm}$. Luas genangan yang tergenang pada skenario genangan $117 \mathrm{~cm}$ adalah 4.172 hektar, sedangkan luas wilayah yang tergenang pada skenario genangan $133 \mathrm{~cm}$ adalah seluas 4.281 hektar. Kerugian akibat banjir rob pada skenario genangan $117 \mathrm{~cm}$ adalah sebesar 50,26 trilyun rupiah, sedangkan kerugian akibat banjir rob pada skenario genangan $133 \mathrm{~cm}$ diperkirakan 50,56 trilyun rupiah.
\end{abstract}

Kata kunci: Pemetaan Partisipatif, Estimasi Kerugian, Banjir Rob, Kabupaten Pekalongan

\section{PENDAHULUAN}

\section{Latar Belakang}

Bencana banjir pesisir merupakan salah satu bencana yang menjadi permasalahan bagi wilayah kepesisiran di dunia (Mardiatno, 2007; Blackett dan Hume, 2007). Seiring dengan adanya fenomena pemanasan global dan perubahan iklim, bencana ini akan semakin besar dampak dan intensitas terjadinya (Marfai dkk, 2013). Kobayashi (2003) menyatakan bahwa kenaikan muka air laut (sea level rise) akan menyebabkan banyaknya wilayah pesisir dan daratan di pulau-pulau kecil dan sangat kecil tenggelam. Kenaikan muka air laut di dunia pada Tahun 2100 diperkirakan akan bertambah sekitar $18 \mathrm{~cm}$ sampai dengan $59 \mathrm{~cm}$ (IPCC, 2007), dengan rerata kenaikan muka air laut adalah sebesar 0,44 $\mathrm{cm} /$ tahun. Gambar 1 menunjukkan bahwa kecenderungan dari kenaikan muka air laut yang 
terjadi di Laut Jawa. Data yang digunakan dalam Gambar 1 diambil dari hasil pencatatan lapangan pasang surut di beberapa stasiun pengukuran di Laut Jawa.

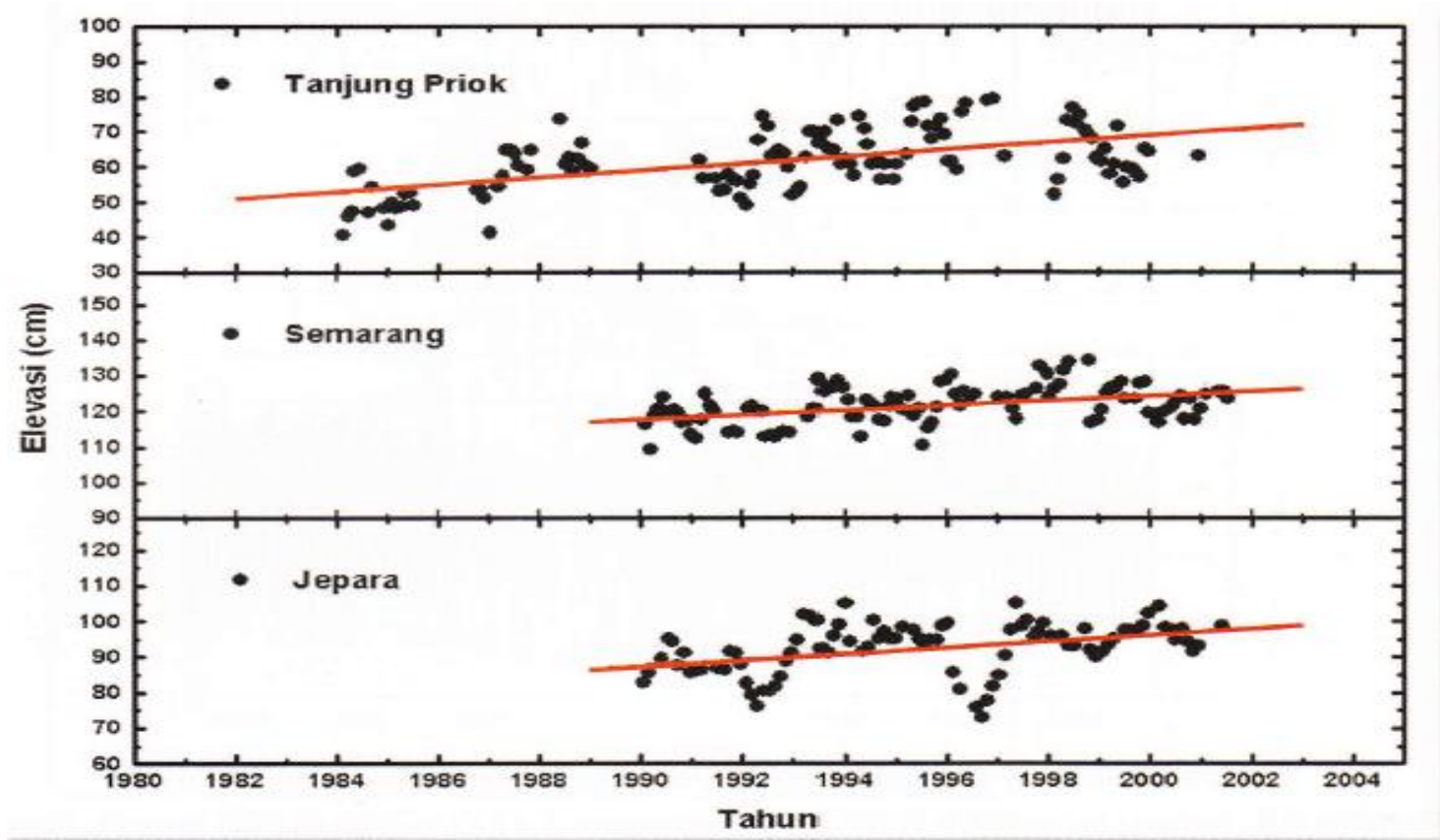

Gambar 1. Trend kenaikan muka air Laut di beberapa stasiun pengukuran di Laut Jawa (Aldrian dkk., 2011)

Kabupaten Pekalongan merupakan salah satu Kabupaten di Provinsi Jawa Tengah yang terletak di Wilayah Kepesisiran Kabupaten Pekalongan. Wilayah Kepesisiran dari Kabupaten ini juga mengalami kerusakan akibat banjir rob. Marfai dkk. (2014) menyebutkan bahwa kerusakan yang terjadi di Kabupaten Pekalongan akibat banjir rob meliputi kerusakan lahan pertanian sawah, kerusakan tambak, kerusakan permukiman dan gedung-gedung fasilitas umum serta kerusakan jalan dan terganggunya sanitasi masyarakat. Dampak ini menyebabkan kegiatan ekonomi tidak dapat berjalan dengan baik, bahkan menyebabkan banyak menyebabkan masyarakat di Wilayah Kepesisiran Kabupaten Pekalongan beralih mata pencaharian.

Berdasarkan kenyataan yang telah disebutkan di atas, maka diperlukan suatu analisis terkait dengan sebaran spasial dan luasan dari wilayah yang mengalami dampak banjir rob di Wilayah Kepesisiran Kabupaten Pekalongan. Hal ini penting untuk dapat menentukan langkah-langkah mitigasi dan pencegahan bencana yang akan dilakukan pada masa mendatang.

\section{Tujuan}

Kajian dalam penelitian ini bertujuan untuk (1) melakukan pemodelan genangan banjir rob berdasarkan pemetaan partisipatif di Wilayah Kepesisiran Kebupaten Pekalongan dengan menggunakan pemodelan spasial, dan (2) mengestimasi kerugian yang mungkin ditimbulkan oleh bencana banjir rob di Wilayah Kepesisiran Kabupaten Pekalongan berdasarkan pada pemetaan partisipatif. 


\section{METODE}

\section{Data yang Digunakan}

Data yang digunakan dalam penelitian ini meliputi:

a. Peta administrasi wilayah kajian skala 1:25.000;

b. Data Penggunaan Lahan di lokasi kajian skala 1:25.000;

c. Data titik ketinggian;

d. Data rata-rata ketinggian banjir rob yang sering terjadi (hasil wawancara);

e. Data nilai ekonomi masing-masing penggunaan lahan;

f. Data ketinggian banjir rob yang paling tinggi yang pernah terjadi di lokasi kajian (hasil wawancara), dan

g. Peta garis pantai sebagai start map dalam iterasi.

\section{Metode Pengumpulan Data}

Data terkait dengan ketinggian rata-rata dan ketinggian banjir rob paling tinggi yang pernah terjadi diperoleh dari kegiatan wawancara dengan masyarakat di lokasi kajian. Wawancara dilakukan di 3 kecamatan, meliputi Kecamatan Tirto, Kecamatan Wonokerto dan Kecamatan Siwalan. Ketiga kecamatan ini terletak di Wilayah Kepesisiran Kabupaten Pekalongan. Jumlah responden untuk masing-masing kecamatan adalah 30 responden, sehingga total responden adalah 90 orang. Selain itu, data yang diperoleh juga dievaluasi dengan pengukuran lapangan berdasarkan tanda-tanda yang ditinggalkan oleh banjir rob pada dinding-dinding bangunan seperti rumah dan bangunan yang lain.

\section{Analisis Data}

\section{a. Pembuatan Digital Elevation Model}

Digital elevation model dibuat dari data titik-titik ketinggian. Data ini merepresentasikan suatu model elevasi dengan format raster. Masing-masing piksel pada data raster tersebut akan memiliki satu nilai ketinggian. Nilai dari masingmasing piksel tersebut diperoleh dari proses interpolasi nilai ketinggian dari titik-titik ketinggian yang dimiliki di lokasi kajian (Burrough dan McDonnell, 1998). Pembuatan data digital elevation model dilakukan dengan menggunakan Sotfware ILWIS.

\section{b. Pembuatan Skenario Genangan Banjir Rob}

Skenario banjir rob dilakukan dengan neighbourhood operation (operasi ketetanggaan) dengan menggunakan Software ILWIS. Start map yang digunakan sebagai awal iterasi adalah data garis pantai. Asumsi yang digunakan adalah bahwa banjir rob yang terjadi masuk ke daratan melalui garis pantai. Skenario ketinggian yang digunakan dalam penelitian ini adalah ketinggian rata-rata banjir rob yang terjadi di lokasi kajian dan ketinggian banjir rob yang pernah terjadi di lokasi kajian berdasarkan pada pemetaan partispatif yang dilakukan.

\section{c. Estimasi Kerugian Akibat Banjir Rob di Wilayah Kepesisiran Kabupaten Pekalongan}

Estimasi kerugian yang terjadi akibat banjir rob dilakukan berdasarkan pada tumpang susun antara peta genangan banjir rob hasil pemodelan spasial dengan 
peta penggunaan lahan di lokasi kajian. Nilai dalam rupiah dari kerugian yang terjadi dihitung dengan menjumlahkan hasil perkalian antara luas masing-masing penggunaan lahan yang terdampak banjir rob dengan nilai ekonomi dari masingmasing penggunaan lahan di lokasi kajian. Nilai ekonomi dari masing-masing penggunaan lahan diperoleh dari hasil wawancara dengan penduduk di wilayah kepesisiran Kabupaten Pekalongan seperti yang dilakukan pada pengumpulan data ketinggian kejadian rob yang telah diebutkan sebelumnya. Metode yang digunakan dalam penelitian ini pernah pula dilakukan oleh Ward et. al. (2010) dan Purnama dkk. (2012).

\section{PEMBAHASAN}

Hasil analisis dari data titik-titik ketinggian dan digital elevation model (Gambar 2 dan Gambar 3), diketahui bahwa Wilayah Kepesisiran Kabupaten Pekalongan memiliki morfologi yang datar di bagian Utara sampai dengan hampir keseluruhan wilayahnya kecuali di bagian Tenggara. Kondisi ini memungkinkan terjadinya banjir rob dengan jangkaun yang jauh. Keberadaan pegunungan di bagian tenggara merupakan penghalang secara alami bagi terjadinya banjir rob. Berdasarkan hasil analisis, diketahui pula bahwa pada ketiga kecamatan yang terdapat di Wilayah Kepesisiran Kabupaten Pekalongan memiliki ketinggian maksimum hanya $3,5 \mathrm{~cm}$.

Hasil wawancara yang dilakukan menunjukkan bahwa ketinggian banjir rob rata-rata yang sering terjadi adalah setinggi $117 \mathrm{~cm}$, sedangkan banjir rob yang paling tinggi yang pernah terjadi adalah $133 \mathrm{~cm}$. Berdasarkan data tersebut, kemudian disusun skenario penggenangan banjir rob di lokasi kajian dengan menggunakan operasi ketetanggaan.

Hasil pengegenangan banjir rob dengan skenario ketinggian $117 \mathrm{~cm}$ menunjukkan bahwa wilayah yang tergenang banjir rob adalah seluas 4.172,85 hektar (Gambar 4), dengan penggunaan lahan berupa permukiman, lahan pertanian sawah irigasi serta tambak menjadi penggunaan lahan yang paling banyak terdampak (Tabel 1). Kondisi yang sama terjadi pada skenario penggenangan dengan ketinggian $133 \mathrm{~cm}$ (Gambar 5). Namun demikian, luas dari penggenangan di skenario ketinggian ini adalah seluas 4.281,01 hektar.

Nilai ekonomi dari masing-masing penggunaan lahan di lokasi kajian ditunjukkan oleh Tabel 2. Berdasarkan hasil wawancara mendalam, nilai penggunaan lahan paling besar menurut wawancara mendalam adalah permukiman. Nilai permukiman ini termasuk barangbarang yang terdapat di dalamnya. Nilai terbesar kedua adalah gedung untuk, ketiga sawah irigasi. Meskipun memiliki nilai yang rendah dibandingkan dengan penggunaan lahan yang lain, keberadaan dari penggunaan lahan pertanian (termasuk tambak) sangat penting bagi ketahan pangan di wilayah Kabupaten Pekalongan. 
SEMINAR NASIONAL GEOGRAFI UMS 2015

$<$ Muh Aris Marfai dkk.>; <Pemetaan Partisipatif untuk Estimasi Kerugian Akibat Banjir Rob

di Kabupaten Pekalongan]>

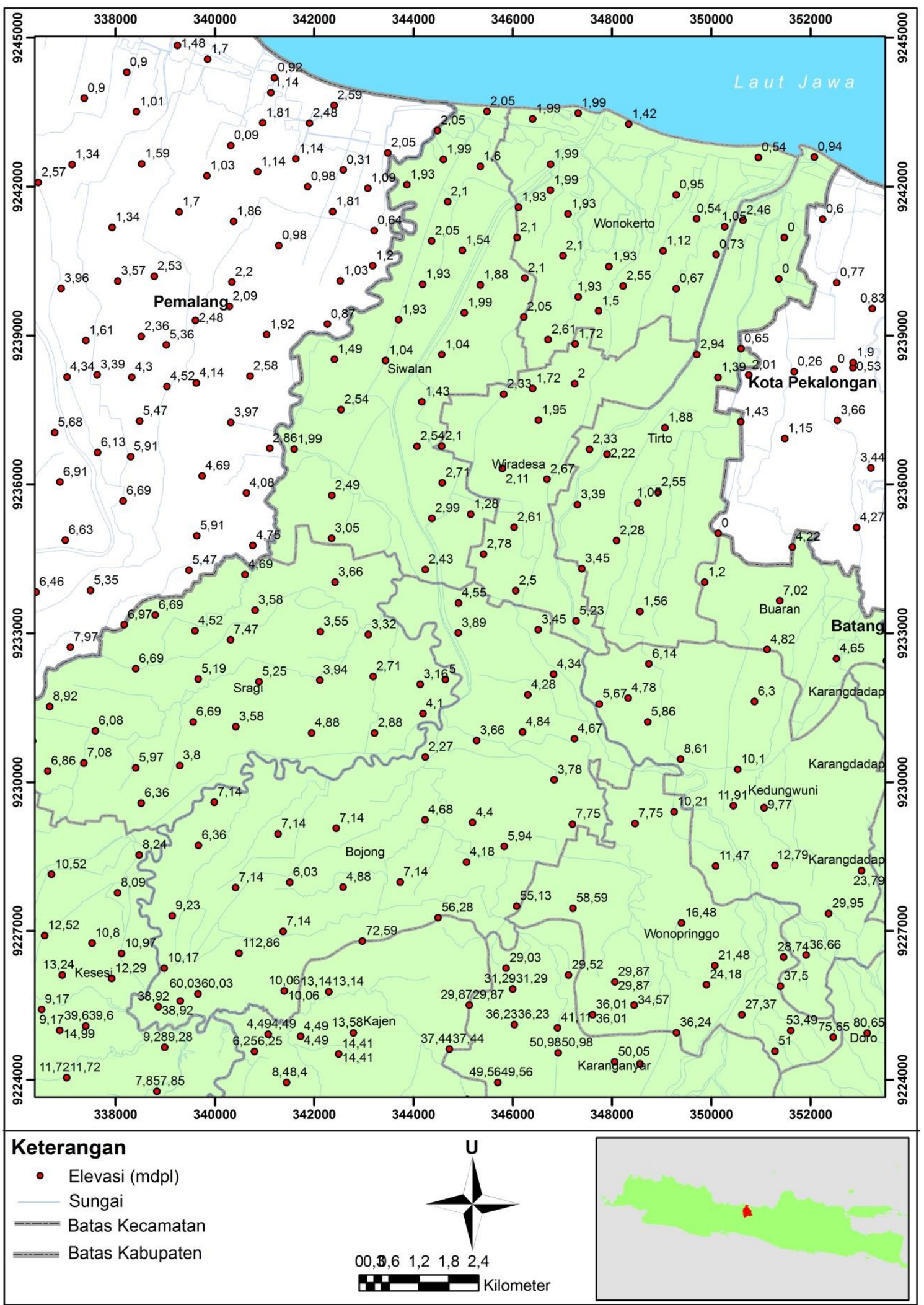

Gambar 2. Peta Titik Elevasi Kabupaten Pekalongan 
SEMINAR NASIONAL GEOGRAFI UMS 2015

$<$ Muh Aris Marfai dkk.>; <Pemetaan Partisipatif untuk Estimasi Kerugian Akibat Banjir Rob di Kabupaten Pekalongan]>



Gambar 3. DEM Kabupaten Pekalongan Hasil Interpolasi Titik Ketinggian 
SEMINAR NASIONAL GEOGRAFI UMS 2015

$<$ Muh Aris Marfai dkk.>; <Pemetaan Partisipatif untuk Estimasi Kerugian Akibat Banjir Rob di Kabupaten Pekalongan]>

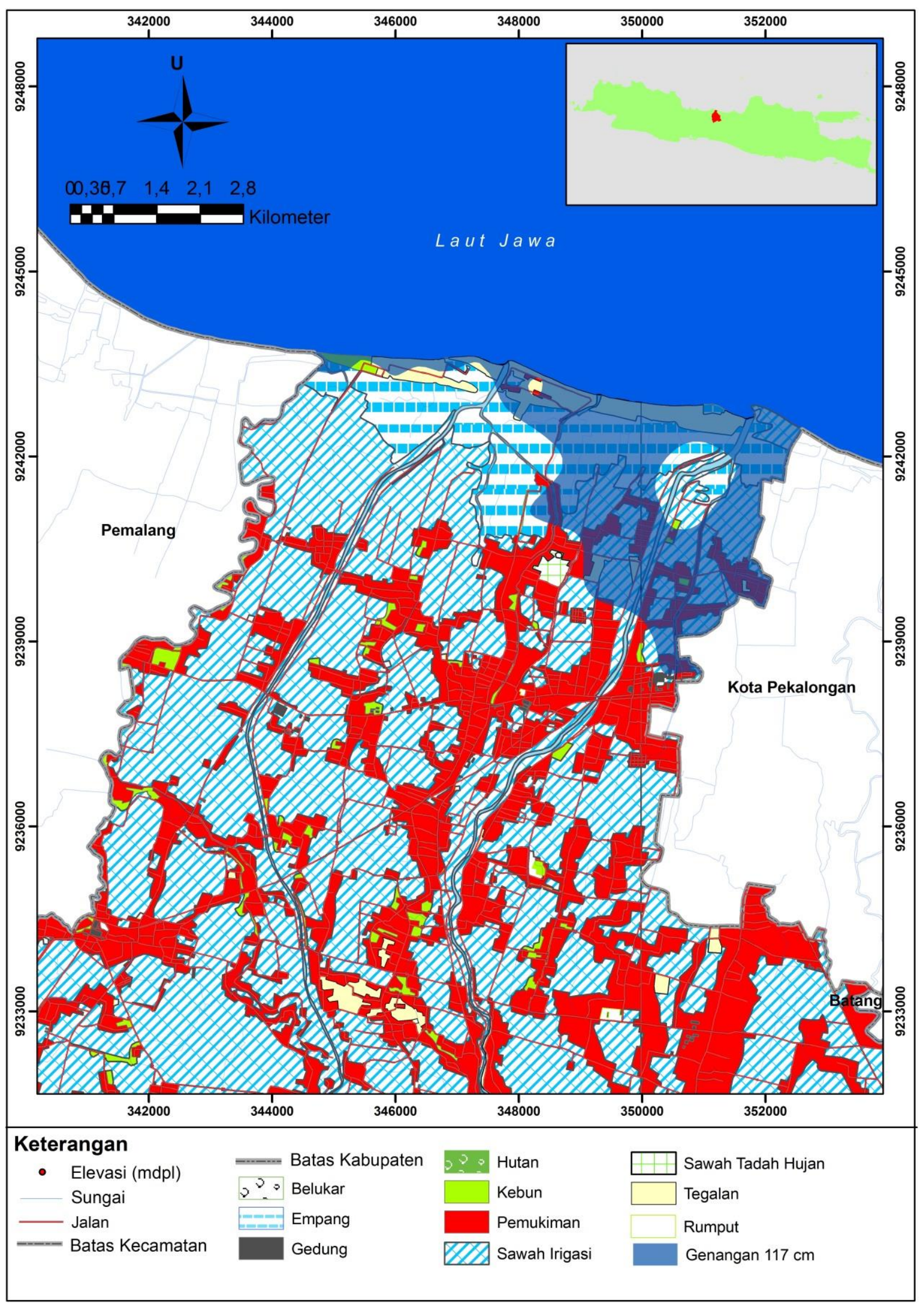

Gambar 4. Peta genangan banjir skenario genangan $117 \mathrm{~cm}$ 
SEMINAR NASIONAL GEOGRAFI UMS 2015

$<$ Muh Aris Marfai dkk.>; <Pemetaan Partisipatif untuk Estimasi Kerugian Akibat Banjir Rob di Kabupaten Pekalongan]>

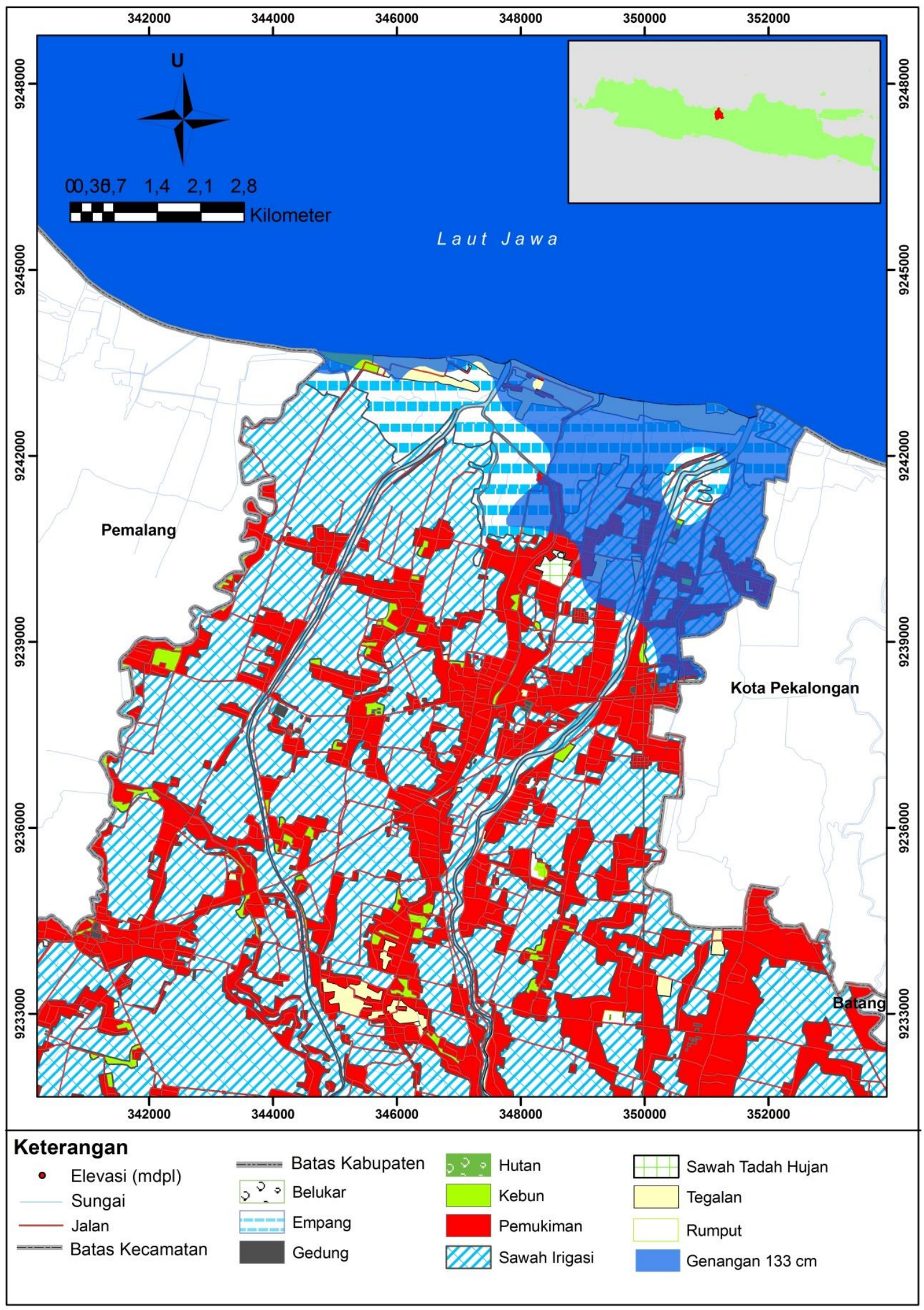

Gambar 5. Peta genangan banjir skenario genangan $133 \mathrm{~cm}$ 
Tabel 1. Luas Masing-Masing Penggunaan Lahan yang Tergenang Banjir Rob Berdasarkan pada Pemodelan Spasial di Kabupaten Pekalongan

\begin{tabular}{|c|c|r|r|}
\hline No & Penggunaan Lahan & Skenario Genangan $\mathbf{1 1 7} \mathbf{~ c m}$ & Skenario Genangan $\mathbf{1 3 3} \mathbf{~ c m ~}$ \\
\hline 1 & Tegalan & 210,20 & 210,20 \\
\hline 2 & Sawah Tadah Hujan & 0 & - \\
\hline 3 & Sawah Irigasi & 688,82 & 688,82 \\
\hline 4 & Rumput & 0 & 2,24 \\
\hline 5 & Pemukiman & $2.582,11$ & $2.587,73$ \\
\hline 6 & Kebun & 21,03 & 21,03 \\
\hline 7 & Gedung & 0,34 & 2,36 \\
\hline 8 & Empang/Tambak & 670,36 & 768,64 \\
\hline 9 & Belukar & 0 & - \\
\hline \multicolumn{2}{|c|}{ Total Wilayah yang } & $4.172,85$ & $\mathbf{4 . 2 8 1 , 0 1}$ \\
\hline \multicolumn{2}{|c|}{ Tergenang (hektar) }
\end{tabular}

Tabel 2. Nilai Ekonomi Masing-Masing Penggunaan Lahan di Lokasi Kajian

\begin{tabular}{|c|l|r|}
\hline No & Penggunaan Lahan & \multicolumn{2}{|c|}{ Harga Per Ha (Juta Rupiah) } \\
\hline 1 & Tegalan & $10.780,00$ \\
\hline 2 & Sawah Tadah Hujan & $9.240,00$ \\
\hline 3 & Sawah Irigasi & $11.947,00$ \\
\hline 4 & Rumput/Belukar & 25,00 \\
\hline 5 & Pemukiman & $14.938,00$ \\
\hline 6 & Kebun & $10.780,00$ \\
\hline 7 & Gedung & $37.335,00$ \\
\hline 8 & Empang/Tambak & $1.418,00$ \\
\hline
\end{tabular}

Sumber: Hasil Wawancara

Hasil estimasi kerugian akibat banjir rob di Wilayah Kepesisiran Pekalongan didasarkan pada hasil pemodelan spasial adalah sebesar 50,26 trilyun rupiah pada skenario genangan $117 \mathrm{~cm}$ adalah sebesar, sedangkan kerugian akibat banjir rob pada skenario genangan $133 \mathrm{~cm}$ diperkirakan 50,56 trilyun rupiah Tabel 3). Perhitungan ini menunjukkan bahwa dampak banjir rob terhadap Wilayah Kepesisiran Kabupaten Pekalongan sangatlah besar. 
Tabel 3. Hasil Perhitungan Nilai Kerugian Akibat Banjir Rob di Wilayah Kepesisiran Kabupaten Pekalongan

\begin{tabular}{|r|c|r|r|}
\hline No & Penggunaan Lahan & Skenario Genangan $\mathbf{1 1 7} \mathbf{~ c m}$ & Skenario Genangan 113 cm \\
\hline 1 & Tegalan & $2,26596 \times 10^{12}$ & $2,26596 \times 10^{12}$ \\
\hline 2 & Sawah Tadah Hujan & 0 & 0 \\
\hline 3 & Sawah Irigasi & 0 & $8,22947 \times 10^{12}$ \\
\hline 4 & Rumput & $3,22947 \mathrm{E} \times 10^{12}$ & 56.866 .880 \\
\hline 5 & Pemukiman & $2,26703 \times 10^{11}$ & $3,86555 \times 10^{13}$ \\
\hline 6 & Kebun & $1,26939 \times 10^{10}$ & $2,26703 \times 10^{11}$ \\
\hline 7 & Gedung & $9,5106 \times 10^{11}$ & $8,81106 \times 10^{10}$ \\
\hline 8 & Empang/Tambak & 0 & $1,09049 \times 10^{12}$ \\
\hline 9 & Belukar & $5,02574 \times 10^{13}$ & 0 \\
\hline \multicolumn{2}{r|}{ Total Kerugian } & & $4,87297 \times 10^{14}$ \\
\hline
\end{tabular}

Sumber: Hasil analisis data

\section{KESIMPULAN}

Berdasarkan pada hasil analisis yang telah dilakukan, maka dapat disimpulkan bahwa ketinggian banjir rob yang sering terjadi di Wilayah Kepesisiran Kabupaten Pekalongan adalah setinggi $117 \mathrm{~cm}$, sedangkan banjir rob yang paling tinggi yang pernah terjadi di lokasi kajian adalah $133 \mathrm{~cm}$. Hasil perhitungan yang dilakukan juga menunjukkan bahwa luas genangan yang tergenang pada skenario genangan $117 \mathrm{~cm}$ adalah 4.172 hektar, sedangkan luas wilayah yang tergenang pada skenario genangan $133 \mathrm{~cm}$ adalah seluas 4.281 hektar. Genangan banjir rob tersebut diestimasi telah menyebabkan kerugian sebesar 50,26 trilyun rupiah pada skenario genangan $117 \mathrm{~cm}$ dan 50,56 trilyun rupiah pada skenario genangan $133 \mathrm{~cm}$.

\section{PENGHARGAAN}

Penelitian ini merupakan bagian dari penelitian Hibah Bersaing Pascasarja Universitas Gadjah Mada 2014 dengan judul "Manajemen Risiko Bencana untuk Peningkatan Ketahanan Pangan (Studi Kasus Banjir Pesisir di Kabupaten Pekalongan, Jawa Tengah".

\section{REFERENSI}

Aldrian, E.; Karmin, M.; dan Budiman. 2011. Adaptasi dan Mitigasi Perubahan Iklim di Indonesia. Jakarta: BMKG.

Blackett, P. dan Hume, T. 2007. Community Involvement in Coastal Hazard Mitigation: Some Insight into Process and Pitfalls. Paper disampaikan dalam seminar Politics of Planning Conference 2007. New Zealand Planning Institute.

Burrough P.A. dan McDonnell R.A. 1998. Principals of Geographical Information System. Oxford University Press, New York.

International Panel for Climate Change (IPCC). 2007. Climate Change 2007: The Physical Science Basis. Cambridge University Press, Cambridge.

Kobayashi, H. 2003. Vulnerability Assessment and Adaptation Strategy to Sea-Level Rise in Indonesian Coastal Urban Areas. National Institute for Land and Infrastructure Management, Japan.

Mardiatno, D. 2007. Kajian spasio-temporal kejadian bencana alam periode 1907-2006 di indonesia. Jurnal Kebencanaan Indonesia, 1(3), 151 - 160. 
Marfai, M.A.; Mardiatno, D.; Cahyadi, A.; Nucifera, F. dan Prihatno, H. 2013. Pemodelan Spasial Bahaya Banjir Rob Berdasarkan Skenario Perubahan Iklimdan Dampaknya di Pesisir Pekalongan. Jurnal Bumi Lestari, Vol. 13(2), 244-256.

Marfai, M.A.; Cahyadi, A.; Kahbullah, A.A.; Hudaya, L.A. dan Tarigan, D.R. 2014. Dampak Bencana Banjir Pesisir dan Adaptasi Masyarakat terhadapnya di Kabupaten Pekalongan. Makalah dalam Pekan IImiah Tahunan Ikatan Geograf Indonesia (PIT IGI), 15 November 2014. Yogyakarta: Universitas Negeri Yogyakarta.

Purnama, IGL.; Marfai, A.; Hadmoko, DS.; Mutaqin, B.W. 2012. Pemodelan banjir rob dengan skenario kenaikan muka air laut akibat perubahan iklim global: Integrasi teknologi sistem informasi geografis berbasis raster dan remote sensing untuk studi kota pesisir Jakarta. Laporan Penelitian. Hibah Multidisiplin DIKTI 2012

Ward P.J.; Marfai, M.A.; Yulianto F.; Hizbaron, D.R.; dan Aerts, J.C.J.H. 2010. "Coastal inundation and damage exposure estimation: a case study for Jakarta". Natural Hazards, 56, 899-916. 